\title{
Supporting homeless people living with HIV
}

\author{
Ailsa Cameron \\ From $16^{\text {th }}$ International Symposium on HIV and Emerging Infectious Diseases \\ Marseille, France. 24-26 March 2010
}

\section{Background}

Homelessness impacts on all areas of a person's life. However for homeless people living with HIV the stigma associated with the disease can lead to reluctance to seek any support. This paper reports findings from an evaluation of a 'Housing Support and Outreach and Referral' service developed to support people living with HIV. The paper highlights the importance of coordinating services across agency boundaries as a means of addressing the complexity of need experienced by homeless people living with HIV.

\section{Methods}

Two sources of data collection were used: quarterly project evaluation reports and interviews with professionals and service users. The evaluation reports recorded progress against aims and objectives, for example the number of clients for whom a tenancy had been arranged, whether or not these tenancies were sustained; the number of clients registered with health care services; whether or not they maintained contact with services and how service users perceived their own health to be.

\section{Results}

Over the course of the evaluation the service accepted 27 referrals. Of these, 15 people received tenancy support of who 12 had previously been rough sleeping or living in insecure accommodation. At the end of the evaluation period all of these tenancies had been maintained. At referral only 9 of the 27 were registered with a General Practitioner however at the end of the period all were registered. Additionally 12 people were helped to register with an HIV clinic and a further 5 people were supported to re-engage with HIV services. Monitoring data from the services showed that CD4 counts for 5 service users had improved. Interviews with service users suggested real improvements in their own

\footnotetext{
Correspondence: A.Cameron@Bris.ac.uk
}

University of Bristol, Bristol, UK perceptions of their health status and in their experiences of healthcare services.

\section{Discussion}

The evaluation of this small scale service demonstrates significant improvements for individual service-users in terms of their housing status, their contact with specialist and generic healthcare services and their own perceptions of their health status. The evaluation illustrates the importance of collaborative working as a health promotion strategy to meet the complex needs of people living with HIV who were homeless.

Published: 11 May 2010

doi:10.1186/1742-4690-7-S1-P161

Cite this article as: Cameron: Supporting homeless people living with HIV. Retrovirology 2010 7(Suppl 1):P161.
Submit your next manuscript to BioMed Central and take full advantage of:

- Convenient online submission

- Thorough peer review

- No space constraints or color figure charges

- Immediate publication on acceptance

- Inclusion in PubMed, CAS, Scopus and Google Scholar

- Research which is freely available for redistribution

Submit your manuscript at www.biomedcentral.com/submit
C Biomed Central 